\title{
Examining the Factors Impact People's Intention to Adoption of E-Banking in Mogadishu-Somalia
}

\author{
Abdifatah Ibrahin Yousuf, Lei Shanyu \\ School of Economics and Management, Dalian University of Technology, Dalian, China \\ Email: faabdi143@gmail.com
}

How to cite this paper: Yousuf, A. I., \& Shanyu, L. (2021). Examining the Factors Impact People's Intention to Adoption of E-Banking in Mogadishu-Somalia. American Journal of Industrial and Business Management, 11, 1218-1236.

https://doi.org/10.4236/ajibm.2021.1112073

Received: November 23, 2021

Accepted: December 24, 2021

Published: December 27, 2021

Copyright $\odot 2021$ by author(s) and Scientific Research Publishing Inc. This work is licensed under the Creative Commons Attribution International License (CC BY 4.0).

http://creativecommons.org/licenses/by/4.0/

(c) (i) Open Access

\begin{abstract}
E-banking last few years has become one of the most common popular banking systems. Most banks are improved by adopting this new technology, allowing access to a series of banking services anytime and anywhere. This research attempts to build the knowledge or understand on examining the factors that affect people's intention to use e-banking in Mogadishu-Somalia contextual. This paper used the survey questionnaires to conduct online interviews to solve the research questions of the quantitative and qualitative design, primary sample data from 452 e-banking users on residence in Mogadishu. A study model was proposed by combining the conceptual framework (TAM) to construct perceived credibility, risk, and Structural Equation Modeling (SEM) to analyze the collected data. The outcome reveals that perceived ease of use, perceived usefulness, perceived risk, perceived credibility all have a positive impact intention to the adoption of e-banking. The study indicates the enhancing credibility and satisfaction with e-banking users in Somalia.
\end{abstract}

\section{Keywords}

E-Banking, Somalia, Technology Acceptance Model (TAM) Perceived Risk, Perceive Credibility

\section{Introduction}

E-banks are gradually operating websites from which customers can request account balances. In Austria, Asia, and Scandinavia, over 75 percent of all banks provide Internet banking based on e-banking, the central banks in the United States. Just about 6 percent of U.S. customers have Internet service bank accounts. However, up to one-third of Fi's bank customers get profit from 
e-banking. The global economy has undergone a massive transition over the last few decades, with 23,000 shopper's data in 25 European countries, the USA, Asia, and Africa. Not only do 54 percent of shoppers purchase items online on a daily and weekly basis (PwC, 2016) (Masoud et al., 2017), Somalia's banking industry is regarded as one of the most essential financial and economic industries in Somalia. Most banks have adapted modern information and communication technologies to improve service quality, resulting in a rapid transformation. It is reasoned that Somalia banks are an attempt to differentiate themselves in a highly competing market. Which has led to the need to implement e-banking system and enable clients to use them in order to keep up with technological advances and to identify the worldwide rising success of the e-banking (Mwiya et al., 2017) (Sayid et al., 2012), Hormuud Telecom in Mogadishu, Golis Telecom in Bossaso, and Telesom in Hargeisa created first a mobile wallet M-money transfer service in 2009, known as Zaad service or Sahal financial service, for the first time due to access and rapid growth of telecommunications, allowing customers to transfer money, pay bills and buy products and services using their mobile phones. This product is becoming more popular in the Somali community from south to north within a brief period due to its reduced risk of carrying cash around and removing the traditional method to use money transfer companies (Sayid et al., 2012). One of the e-commerce progresses is simplified in the Internet-founded competencies of the enterprise. Information communication technology (ICT) creativity has become a crucial role sector of the economy in developing and developed countries. It's also shown in the integration and cooperation of all nations in the world. The current study focuses on the factor that impacts customer intention to adopt e-banking relevant capital city of Somalia-Mogadishu. E-banking is one of the vital roles in every country's economic sectors because of fostering economic growth through efficiency and customer satisfaction to obtain convenient services (Fonchamnyo, 2013). Also, the enhanced TAM is empirically evaluated to confirm its application in driving the adoption of e-banking. Four parts are split into the remainder of the document: the second section includes a summary of e-banking in Somalia. Literature on the hypotheses test can justify the adoption of e-banking and information systems (Mwiya et al., 2017). Above four decades, banks have been using electronic fund transfers (EFT) to communicate account information across personal communication networks (Hu \& Liao, 2011). Internet banking is a new method of performing banking transactions that have piqued the interest of many banks as a viable alternative to traditional banking. It is a highly data-intensive action that heavily relies on information technology to obtain, structure, and delivers financial data to all customers. Internet banking has undergone substantial operational changes as a result of developments in information technology (Kale \& Mesiranta, 2008). The Internet has existed for a long time, making Internet Banking a viable option for many firms and people. These rapid advancements in the internet and electronic banking have prompted the banking industry to urge customers to bank online (Riffai et al., 2012). As a result, internet banking 
has become the quickest commercial sector (Poon, 2003). Across the decades, the tremendous rise of internet banking has provided effective means of providing consumers. With the fast-growing number of internet users, it's very simple to access the internet, comfort, effectiveness, and profits are all aspects that have prompted banks to adopt e-banking. Electronic banking is the current delivery mode in many rapidly developing countries, and there is a broad consensus that this will have a significant impact on the banking sector. On the basis of (Surana \& Sullivan, 2000), the development and advancement of electronic technology, particularly the Internet, may result in the displacement of numerous of today's well-developed banking sectors. With the development and rise of the Internet, the bank branch's main significant relevance is under danger. Market participants can usage especially via the Internet, making it simple to buy or sell from the convenience of one's own homes and offices. Each bank aims to gain as much market share as possible. In today's competitive world, a bank's success is based on customer focus, partitioning, positioning, and targeted marketing using information technology (IT). Due to "technologies" such as electronic banking on the Internet, emerging countries' banking sectors are competing with worldwide large-scale banks and are unable to ignore the needs of their customers. Customers now have various options for choosing the system provided they require at a price they are willing to accept (Bradley \& Stewart, 2013). Understanding the factors that influence Internet usage will result in an increase in Internet banking usage. Furthermore, the breadth of services offered and the bank's name are the most important considerations when selecting a bank.

\section{E-Banking of Somalia}

During the Somali civil war, the international community concentrated on Somalia's political and security issues; the financial sector switched to hawala or money transfer services, a mechanism that most banks did not recognize. However, the financial industry has been rising quite fast in recent years. The Premier Bank, Somalia's domestic bank, declared in 2014 that the government had approved Internet banking services by commercial banks. Salaam Somali bank has also officially stated that they will provide this kind of service, citing their website, we understand you have more important tasks to do with your time. That's why we've combined the Internet's strength with the latest technologies to give you the best possible online banking experience. You will do your banking more efficiently with our online banking than ever before. It is also acknowledged to us that security is a significant characteristic of any method of online banking. We also introduced secure technology to protection you from identity theft and fraud for this purpose. The banks authorized under the Central Government of Somalia are currently approved to provide Internet banking services in Somalia. These include Dahabshiil International Bank, Premier Bank of Somalia International Bank (IBS), and Salaam Somali Bank, which have announced that they have launched an internet banking service. Internet banking has become a modern service delivery platform for banks. As a consequence, banks 
have been gradually providing their services online. Online banking has become more convenient for banks than for customers. Though, clients' acceptance and trust in the scheme remain a main factor in ensuring Internet banking success. Therefore, the study of this investigation is to examine the factors that impact people's intention to adoption of e-banking in Mogadishu-Somalia.

\section{Literature Review \& Development Hypotheses}

\subsection{E-Banking}

Electronic banking is essential for delivering bank services more effectively and offering more, quicker, and cheaper goods through their personal computers. Customers can search for the most critical bank products and services within 24 hours (Xiao et al., 2017). Last few years, the banking industry has held the top spot in the e-business world. The e-banking Movement has transformed the banking industry by breaking down barriers and creating more opportunities. E-banking, to put it simply, is the supply of banking products and services via electronic distribution platforms. Automatic teller machines (ATMs) and telephone transactions have both been considered forms of electronic banking. It has already undergone a transformation as a result of the internet. All banks and clients benefit from the new daily route, which makes banking transactions easier. Customers can get quicker access to bank services via the internet, which is more convenient and accessible around all times, regardless of their area (Low \& Abdul, 2013). The internet banking revolution has changed the way people bank, as well as introducing new action plans for investing in banking information and communication technologies (Sabi, 2014). Intranet is a network that links several sites within a company and provides the connection to the head office. These intranet networks are exclusive to the companies that utilize them (Vyas, 2012). The phrase "internet banking" is currently used to refer to a new type of banking system. Internet banking is described as the use of the internet to conduct banking transactions like a money transfers, accessing current account data, paying bills and checking account balances, acquiring financial products, and paying loans and bank deposits (Okari \& Box, 2017). The West African country like Nigeria is few developing countries in Africa content that has completely understood the value of education. In the world of technology, however, reasons such as a lack of confidence in internet banking security measures are due to resistance and low adoption of electronic banking in Nigeria (Xiao et al., 2017). Customers have access to banking products and services through routine physical transactions with bank tellers in traditional banking procedures. This method of providing e-banking services generated an Inconsistency between consumer expectations and banking capacities; consumers can only access financial services at particular places and throughout operating hours. The banks are now willing to offer their goods and services to customers from anywhere and via various Platforms for contact, such as automated teller machine (ATM) the Internet, mobile networks, etc., with the advent of technological advances. These Proce- 
dures of providing goods and services to banks are referred to as e-banking using electronic communication networks. (Maduku, 2014) stated they contribute to higher returns and market adoption, assuming higher returns and market penetration? Like retail banks elsewhere globally, South African Banks for Retail invest vast sums of capital in providing facilities for e-banking? However, the swift acceptance of these systems for e-banking, the fast implementation of these e-banking systems are still in distrust. Every solution focused on achieving rapid acceptance and utilization of these e-banking service providers must be built on a thorough considerate of the aspects that impact consumer acceptance and use (Maduku, 2014). This finding contributes to confidence in the e-banking service, consumer knowledge of e-banking systems and perceived self-efficacy, and the (TAM) concepts of perceived usefulness and ease of use to advance Network predictor variables adoption mobile banking services in South Africa. The design of a cross-sectional association descriptive study was used for this analysis to obtain information through self-administered questionnaires. Data from 394 clients of South Africa's five necessary commercial banks, the studied results indicated that the above variables lead significantly to the adoption and utilize of the Internet and cellphone banking.

\subsubsection{Technology Acceptance Model (TAM)}

TAM, revealed by (Davis, 1989) defines TRA modification for user adoption simulation of information technology. TAM's objective is to explain the general determinants of machine adoption, describing user behavior across various end-user computing technologies and user behavior, user populations, while at the same time being both parsimonious and theoretically justified. Ideally, one would like a helpful model for forecasting and the explanation so that scientists and experts can recognize why a specific device might be unacceptable and follow effective disciplinary measures. There is a crucial TAM reason to provide a framework for tracking the effect on internal beliefs of external influences, Attitudes, and purposes. TAM was considered by identifying a limited number of main factors recommended by (Davis, 2014) past researchers to accomplish these objectives. They deal with and use the intelligent and affecting bases of machine acceptance as a theoretical foundation for designing the academic connections between these theories of reasoned action (TRA) factors. Several changes have been made to the fundamental TRA technique, backed by availability theory and evidence, based on these goals for. TAM claims that there are two primary factors, perceived use/fullness and perceived ease of use for machine acceptance behaviors; of immediate relevance. Figure 1 below shows original framework of (TAM).

\subsubsection{Perceived Usefulness}

Following (Davis, 1989) P.U. is defined as "the degree to which a person believes that using a particular system would enhance his or her job performance" (Kabeer, 2013). The sector of the relevance of e-banking P.U had been commonly 


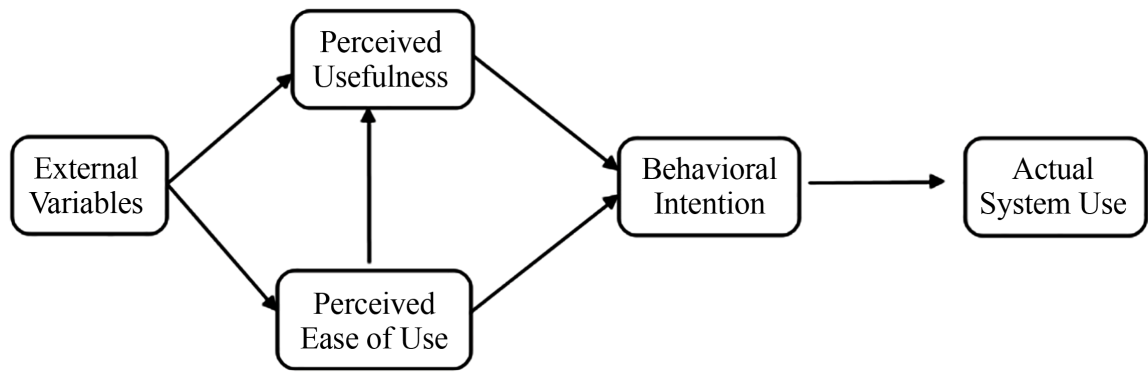

Figure 1. Technology Acceptance Model (TAM).

identified after previously finding that perceived usefulness directly influences internet banking use. The PU has a significant impact on the intention of students in higher education in Pakistan to adopt Internet banking services (Khurshid, 2014); P.U. has defined the level at which customers can trust the online banking service to improve their efficiency. P.U. also relates to the attitude towards the use of e-banking (Case \& Dashen, 2016). This analysis refers to the degree to which persons assume that e-banking is more beneficial than conventional ways of conducting banking, via purchases, via loans. Such advantages include allowing users to perform banking tasks at any time efficiently and reliably at a lower rate. the Past researchers of e-banking acceptance have constantly shown that P.U. a direct relevance on intention to adopt e-banking service usage (Case \& Dashen, 2016; Khurshid, 2014; Mohamed et al., 2020; Xiao et al., 2017). As one of TAM's essential principles, the vast majority of investigations have positively influenced people's intention to use the e-banking services. It was discovered that the P.U. had a huger impact on people's intentions to use e-banking. Additionally, (Wu et al., 2010) revealed that Perceived usefulness significantly affects the intentions of Taiwan's citizens to implement e-banking services. So, the better the perceived usefulness of the e-banking system, the more likely customers are to adopt e-banking services. Clients can benefit from internet banking in two ways: positively and negatively. Positive advantages refer to the tangible outcomes that internet banking provides, such as easy access and improved financial transparency. Negative advantages, such as the ability to conduct banking activities from anywhere in the world and have access to 24-hour banking service, are less concrete and difficult to quantify.

H1: There's positive related perceived usefulness to the adoption of e-banking in Mogadishu-Somalia.

\subsubsection{Perceived Ease of Use}

(Davis, 1989) defined "the degree to which a person believes that using a particular system would enhance his or her job performance” (Case \& Dashen, 2016). In this analysis, perceived ease of use is how the person trusts that using e-banking facilities will be effort-free. The performance, efficiency, and performance of a system will only be validated by the degree that its users approve it through its ability to meet their needs (Xiao et al., 2017). Perceived ease of use is a helpful concept in recognizing the intention of customers to use newer tech- 
nology. It is suspected to play a significant role in adopting e-banking system in China's Province Shandong. Cyprus banks simplified the perceived ease of use, and perceived usefulness is a strong favorable association to the adoption of e-banking (Alkailani, 2016). It was also highlighted that, while a specific user may appear to be helpful, potential customers may consider that the systems are very difficult to use and that the effort necessary to use the program outweighs the significant benefits. Perceived ease of use ensures that current standard procedures with minor variance can be extended to the situation at hand (Kabeer, 2013). Almost ten studied found (PEOU) has been revealed to affect the behavioral intention significantly use of Internet banking. Additionally, with less ambiguity in the dependent on these results, it is hugely anticipated that the general causations observed in the technology acceptance model (TAM) are correspondingly related to the network when communicating with the system of services from banking.

PEOU also positive effect on student intention in Mogadishu University of Somalia to implement e-banking services (Mohamed et al., 2020). Perceived ease of use is defined as the extent to which users accept that a particular technique would be productive in its transfers and use. This study improved the hypothesis to justify these contradictory measures.

$\mathrm{H} 2$ : There's positive related perceived ease of use to the adoption of e-banking in Mogadishu-Somalia.

\subsubsection{Perceived Risk}

Perceived risk, including e-banking, is the possibility of failure in creating the desired result of using e-banking services. Most experts have added perceived risk to collecting factors essential for the adoption relationship between perceived risk and e-banking services (Alkailani, 2016). Reliable and safe internet transactions are necessary to the effectiveness of services. Commercial banks include classified financial Transactions that involve high standards of confidentiality and reliability (Case \& Dashen, 2016). Researchers have shown that e-banking users have faced at least one and often more electronic security attacks. Then when it comes to internet banking, this risk has been magnified in scale and implications. The consequence of such a negative experience has had a sustained impact on the level of perceived risk clients had while banks on the website. (Cunningham et al., 2005) found in the preliminary phase; the perceived risk is usually considered an essential factor-consumer purchase method. Customers perceived risk first once they are realize the need for a service or product. Inconvenient in the sight of Consumers implement risk mitigation measures during the second cycle of perceived risk levels, Second and third stages, for example, dependence on specific suggestions, researchers found the perceived risk is significant positive adoption of e-banking (Arora \& Kaur, 2018) (Siraye, 2014) (Ramayah, 2015).

H3: There's a positive related perceived risk to the adoption of e-banking in Mogadishu-Somalia. 


\subsubsection{Perceived Credibility}

Bank credibility is a crucial factor to the consumers pay attention to when dealing with banks of Commerce. (Kabeer, 2013) perceived credibility, the bank must preserve its excellent reputation and must offer consumers trust in its service. Perceived credibility consists of two key components: data privacy. Safety affects the security of data or devices against unauthorized access (Xiao et al., 2017). P.C. involves individuals' intent to use Internet banking. The lack of federal democracy of Somalia (FDS) has been identified as the primary cause of individual customer dissatisfaction, combined with other variables. E-banking facilities suggested a significant impact of perceived credibility (P.C.) on e-banking service use. The system's possible security risks and personal data safety are related to credibility (Oni \& Ayo, 2010). Perceived credibility; is identified as the assumption of users that their transaction information and individual data are secured against unauthorized access. P.C. is about the unique trust that a user has in the system to conduct a transaction and preserve confidential information safety safely there's a positive related perceived credibility to the adoption of e-banking in Mogadishu-Somalia.

H4: there's a positive related perceived credibility to the adoption of e-banking in Mogadishu-Somalia.

\section{Methodology and Data Collection}

This study focuses on the factor impact customer intention to adopt e-banking users in Mogadishu-Somalia It has generally shown the effectiveness. The degree of the adoption of e-banking is also evidencing the growth and popularity of ICT in Somalia. This paper is based on the technology acceptance model (TAM) to construct perceived credibility, perceived risk examining the factors that impact people's intention to Adopt E-banking in Mogadishu-Somalia. This paper is used the survey questionnaires to conduct online interviews to solve the research questions of the quantitative and qualitative data from 452 e-banking users on residence in Mogadishu to explore the four key segments of the perceived ease of use perceived usefulness, perceived credibility, perceived risk. The purpose of this paper is to examine the factors that influence the customer's adoption of e-banking in Mogadishu, Somalia.

\section{Measurement Scales}

A careful review of the literature on factor impact customer intention to adopt e-banking has been done to select adequate measurement items. The items of Perceived usefulness, Perceived ease of use, Perceived risk, Perceived credibility, adoption of e-banking was adopted from (Zhou et al., 2016; Zhou et al., 2009; Reynolds et al., 2006). The questionnaire was interpreted into the Somali language by two English tutors help to correct items, and e-banking experts improved. As a result, all items of the present study were confirmed in past researchers reported. We questioned two college association tutors from the Dalian University of Technology's School of Economics and Management to doublecheck the language and presentation of the designated items in the current 
study. With the help of the academics mentioned above, 22 items were selected for the pilot survey. In October 2020, a pilot assessment was conducted to identify the validity and phrasing of the selection items. A total of 100 people (e-banking customers) were questioned, and the outcomes were utilized to enhance the wording and eliminate the themes that are least important. Twenty-two items were kept for the final survey once this step was completed.

All questions were rated on a 5-point Likert scale that ranged from "strongly disagree" to "strongly agree", with "neutral" serving as the mid-point anchor. Items assessing the same variable were gathered, as indicated by (Davis \& Venkatesh, 1996). According to Davis \& Venkatesh, 1996, grouping items is more acceptable for responders. Table 1 has a complete list of the items.

\section{Results}

\subsection{Socio-Demographic Information}

Table 2 below is the list of social-demographic characteristics; the result from 452 participants $54 \%$ was male, and $46 \%$ female in terms of age group as indicated in the table below, $40.3 \%$ of 452 respondents were age group of 31 up to 40 with an age group of 41 to 50 with $29.9 \%$ with the age of 20 to $30,13.7 \%$ and

Table 1. Social-demographic characteristics.

\begin{tabular}{|c|c|c|c|c|}
\hline Attributes & Sub-group & Frequency & Percentage \% & Cumul \% \\
\hline \multirow{2}{*}{ Gender } & Male & 244 & $54 \%$ & $54 \%$ \\
\hline & Female & 208 & $46 \%$ & $100 \%$ \\
\hline \multirow{5}{*}{ Age group } & $20-30$ & 62 & $13.7 \%$ & $13.7 \%$ \\
\hline & $31-40$ & 182 & $40.3 \%$ & $54 \%$ \\
\hline & $41-50$ & 135 & $29.9 \%$ & $83.3 \%$ \\
\hline & $51-60$ & 56 & $12.4 \%$ & $96.2 \%$ \\
\hline & More than 60 & 17 & $3 \%$ & $100 \%$ \\
\hline \multirow{5}{*}{ Education Level } & High School & 86 & $19 \%$ & $19 \%$ \\
\hline & Diploma & 249 & $55.1 \%$ & $74.1 \%$ \\
\hline & Bachelor degree & 86 & $19 \%$ & $93.1 \%$ \\
\hline & Master & 16 & $3.5 \%$ & $96.7 \%$ \\
\hline & Ph.D. & 15 & $3.3 \%$ & $100 \%$ \\
\hline \multirow{4}{*}{ Occupation } & Student & 333 & $40 \%$ & $40 \%$ \\
\hline & Employee & 275 & $33 \%$ & $73 \%$ \\
\hline & Unemployed & 212 & $26 \%$ & $99 \%$ \\
\hline & Retired & 8 & $1 \%$ & $100 \%$ \\
\hline \multirow{5}{*}{ Monthly Income } & $200-300 \$$ & 69 & $15.3 \%$ & $15.3 \%$ \\
\hline & $300-400 \$$ & 192 & $42.5 \%$ & $57.7 \%$ \\
\hline & $400-500 \$$ & 121 & $26.8 \%$ & $84.5 \%$ \\
\hline & $600-700 \$$ & 47 & $10.4 \%$ & $94.9 \%$ \\
\hline & $700 \$$ - above & 23 & $5.1 \%$ & $100 \%$ \\
\hline
\end{tabular}


remaining 51 to $6012.4 \%$ in terms of education level $55.1 \%$ of the largest percentage of respondents have a diploma and 3.3\% of the lowest rate of respondents have Ph.D. also the $19 \%$ respondents have bachelor degree $19 \%$ respondents high School and $3.5 \%$ of respondents have master degree, the occupation $26 \%$ respondents were

Table 2. Latent variables with their indicator.

\begin{tabular}{|c|c|c|}
\hline constructs & items & wording \\
\hline $\begin{array}{l}\text { Perceived } \\
\text { usefulness }\end{array}$ & $\begin{array}{l}\text { PU1 } \\
\text { PU2 } \\
\text { PU3 } \\
\text { PU4 } \\
\text { PU5 }\end{array}$ & $\begin{array}{l}\text { E-Banking services enable users to complete banking } \\
\text { activities more quickly and easily? } \\
\text { E-Banking service is convenient in terms of time? } \\
\text { E-Banking service is convenient, in terms of } 7 \text { days and } \\
24 \text {-hour services, to access bank account and? } \\
\text { E-Banking service is more accessible to users than visiting } \\
\text { a bank? } \\
\text { The transactions in any of the E-Banking services are at } \\
\text { a lower price, or at no cost? }\end{array}$ \\
\hline $\begin{array}{l}\text { Perceived } \\
\text { ease of use }\end{array}$ & $\begin{array}{l}\text { PUE1 } \\
\text { PUE2 } \\
\text { PUE3 } \\
\text { PUE4 } \\
\text { PUE5 }\end{array}$ & $\begin{array}{l}\text { E-Banking makes it easier to do banking activities? } \\
\text { In the case of mobile and agent banking, consumers can } \\
\text { simply use their cell phones to access banking services? } \\
\text { E-Banking is simple to use from the bank's perspective to } \\
\text { complete banking tasks? } \\
\text { When launching E-Banking services to the extent predicted, } \\
\text { the bank's management offers training courses for its } \\
\text { employees...? } \\
\text { Using E-Banking systems simplify the activity of workers } \\
\text { to deliver service to customers? }\end{array}$ \\
\hline $\begin{array}{l}\text { Perceived } \\
\text { risk }\end{array}$ & $\begin{array}{l}\text { PR1 } \\
\text { PR2 } \\
\text { PR3 } \\
\text { PR4 }\end{array}$ & $\begin{array}{l}\text { Customers of our bank fear risk to use E-Banking? } \\
\text { Lack of confidence with the security aspects considered as } \\
\text { challenges for the adoption of e-bank? } \\
\text { In the case of using E-Banking, security risk affects user's } \\
\text { decision to use the system? } \\
\text { Lack of trust is considered as challenges for the } \\
\text { Adoption of E-Banking system in Somalia? }\end{array}$ \\
\hline $\begin{array}{l}\text { Perceived } \\
\text { credibility }\end{array}$ & $\begin{array}{l}\mathrm{PC} 1 \\
\mathrm{PC} 2 \\
\mathrm{PC} 3 \\
\mathrm{PC} 4\end{array}$ & $\begin{array}{l}\text { The bank I deal with always keeps its promises? } \\
\text { My Bank employees and I have a close and friendly } \\
\text { relationship? } \\
\text { My bank makes very few mistakes when it comes to my } \\
\text { bank transactions? } \\
\text { My bank is always willing to assist me in any way I need. } \\
\text { Definitely, I'll tell a friend about it? }\end{array}$ \\
\hline $\begin{array}{l}\text { Adoption of } \\
\text { e-banking }\end{array}$ & $\begin{array}{l}\text { E-B1 } \\
\text { E-B2 } \\
\text { E-B3 } \\
\text { E-B4 }\end{array}$ & $\begin{array}{l}\text { Customers prefer face-to-face banking service over internet } \\
\text { banking services? } \\
\text { What are the benefits gained by your institution from the } \\
\text { Adoption of ATM, internet banking, mobile and agent } \\
\text { banking system in the delivery of service to customers? } \\
\text { What are the key factors that push your institution to } \\
\text { adopt ATM, internet, mobile and agent banking system? } \\
\text { What are the advantages/reasons that you consider in } \\
\text { implementing E-Banking system? }\end{array}$ \\
\hline
\end{tabular}


Unemployed, and 1\% were the lowest respondents retired, $73 \%$ respondents employee, $40 \%$ respondents students, the majority monthly income $42.5 \%$ between $300-400 \$$, lowest monthly income $15.3 \%$ between $200-300 \$$ and $26.8 \%$ between $400-500 \$ 5.1 \%$ participant are $700 \$$ above received in monthly income.

\section{Normality Check}

In this study, the CFA and SEM will be determined using the Maximum Likelihood estimation method. First, we tested if the data nearly follow a normal distribution. In general terms, complete standards of kurtosis indexes greater than 10 fundamental values of skew indexes larger than 3 indicate a direct violation of normality (Kline, 2015). In this paper, the skewness indexes scale from -1.824 to -0.234 , and the kurtosis indexes range from 1.625 to 5.735 . As a result, we can show Table 3 that there is no violation of normality.

Table 3. Kurtosis and Skewness indexes of the current study data.

\begin{tabular}{|c|c|c|c|}
\hline Constructs & Indicators & Kurtosis & Skewness \\
\hline \multirow{5}{*}{ Perceived usefulness } & PU1 & 2.411 & -0.236 \\
\hline & PU2 & 2.589 & -0.978 \\
\hline & PU3 & 1.926 & -0.092 \\
\hline & PU4 & 1.739 & -0.839 \\
\hline & PU5 & 1.634 & -0.582 \\
\hline \multirow{5}{*}{ Perceived ease of use } & PUE1 & 4.107 & -1.824 \\
\hline & PUE2 & 3.325 & -0.742 \\
\hline & PUE3 & 3.562 & -0.389 \\
\hline & PUE4 & 2.541 & -0.234 \\
\hline & PUE5 & 3.107 & -0.725 \\
\hline \multirow{4}{*}{ Perceived risk } & PR1 & 2.943 & -0.698 \\
\hline & PR2 & 2.768 & -1.578 \\
\hline & PR3 & 2.395 & -0.489 \\
\hline & PR4 & 4.234 & -1.223 \\
\hline \multirow{4}{*}{ Perceived credibility } & $\mathrm{PC} 1$ & 3.424 & -1.138 \\
\hline & PC2 & 2.684 & -0.939 \\
\hline & PC3 & 4.205 & -1.429 \\
\hline & PC4 & 4.837 & -1.309 \\
\hline \multirow{4}{*}{ Adoption of e-banking } & E-B1 & 2.757 & -0.848 \\
\hline & E-B2 & 5.735 & -1.006 \\
\hline & E-B3 & 5.025 & -1.000 \\
\hline & E-B4 & 3.987 & -0.432 \\
\hline
\end{tabular}




\subsection{Goodness of Fit of Measurement Model}

The measurement model's properties were assessed by tested the convergent validity, reliability, and discriminant validity. The value of composite reliability (C.R.) for all factors see Table 4 below was higher than 0.6, so approving the reliability of the model (Bagozzi \& Yi, 1988). Table 4 showed that the factor loadings of all items were larger than 0.5. Also, we checked the values of average variance extracted (AVE) for all constructs which were also higher than 0.5, approving the convergent validity of the model (Fornell \& Larcker, 1981). We evaluated the square root of AVE for each construct of the model (diagonal values) in Table 5 which were higher than inner construct correlations (off-diagonal values), showing discriminant validity for the model Table 4 showed that the measurement model lights the condition for the reliability and validity of the constructs and discriminant validity. Professional thoughts demonstrated satisfactory validity in terms of instrument validity. Four professional commentators, both local and international, have been invited to validate the produced instrument in terms of relevancy and careful language. The instrument validation was successful appreciations to the specialists' good response. Cronbach's Alphas ( $\alpha$ ) test was used to assess the reliability of the constructed instrument, with a significance level of $(\alpha \geq 0.7)$ as recommended in (Geebren et al., 2021). The purpose of the factor analysis test was to ensure that the degree of relevance of each item in the design was correct. First, the measurement model's properties were evaluated by checking the convergent validity, reliability, and discriminant validity.

To see if the measurement model matches the sample adequately, several goodness-of-fit indices are used. For the data results, the $p$-value of the Chi-square was $0.000\left(\chi^{2}=478,392, \mathrm{df}=156\right)$. For a proper model fit, the p-value should be greater than 0.05 , as a rule of thumb. In contrast, we discovered that the Chi-square is overly sensitive for the samples due to the sample size effect, implying that this chi-square test nearly rejects the model (Bentler \& Bonett, 1980). As a result, using the normed Chi-square ( $\chi^{2} / \mathrm{df}$ ) (Wheaton et al., 2014 ) is one way to resolve the issue of sample size impact. A normed Chi-square between 1 and 5 was reported by (Wheaton, Muthen, Alwin, \& Summers, 2014). In this analysis, the samples' value was $\chi^{2} / \mathrm{df}=3.06$, indicating an acceptable match. Other indices such as the Root Mean Square Error of Approximation (RMSEA), Standardized Root Mean Square Residual (SRMR), The Comparative Fit Index (CFI), Normed-Fit Index (NFI), and Tucker Lewis Index (TLI) were used to verify whether the model fit. The CFI and TLI values should be equal to or higher than 0.95 , and the RMSEA should be less than 0.06 , and the SRMR should be less than 0.08 (Markus, 2012) (Hu et al., 2009). All of the measurement model's applicable fit indexes $\left(\chi^{2}=478,392, \mathrm{df}=156, p<0.001 ; \chi^{2} / \mathrm{df}=\right.$ 3.06; CFI $=0.964$; TLI $=0.976$; RMSEA $=0.041$; SMR $=0.058$ ) were within the expected limits, demonstrating that the measurement model fulfilled all of the model fit requirements. Table 6 below shows the structural equation modeling results. 
Table 4. Validity and reliability of the measurement model.

\begin{tabular}{|c|c|c|c|c|c|}
\hline Constructs & Items & $\begin{array}{l}\text { Factors } \\
\text { loading }\end{array}$ & AVE & $\begin{array}{c}\text { Cronbach's } \\
\text { Alpha }\end{array}$ & C.R. \\
\hline Perceived usefulness & $\begin{array}{l}\text { PU1 } \\
\text { PU2 } \\
\text { PU3 } \\
\text { PU4 } \\
\text { PU5 }\end{array}$ & $\begin{array}{l}0.624 \\
0.717 \\
0.684 \\
0.964 \\
0.824 \\
0.791\end{array}$ & 0.6 & 0.842 & 0.898 \\
\hline Perceived ease of use & $\begin{array}{l}\text { PUE1 } \\
\text { PUE2 } \\
\text { PUE3 } \\
\text { PUE4 } \\
\text { PUE5 }\end{array}$ & $\begin{array}{l}0.743 \\
0.654 \\
0.765 \\
0.957\end{array}$ & 0.62 & 0.811 & 0.864 \\
\hline Perceived risk & $\begin{array}{l}\text { PR1 } \\
\text { PR2 } \\
\text { PR3 } \\
\text { PR4 }\end{array}$ & $\begin{array}{l}0.605 \\
0.798 \\
0.897 \\
0.856\end{array}$ & 0.635 & 0.845 & 0.872 \\
\hline Perceived credibility & $\begin{array}{l}\text { PC1 } \\
\text { PC2 } \\
\text { PC3 } \\
\text { PC4 }\end{array}$ & $\begin{array}{l}0.852 \\
0.701 \\
0.892\end{array}$ & 0.671 & 0.819 & 0.858 \\
\hline Adoption of e-banking & $\begin{array}{l}\text { E-B1 } \\
\text { E-B2 } \\
\text { E-B3 } \\
\text { E-B4 }\end{array}$ & $\begin{array}{l}0.907 \\
0.653 \\
0.897 \\
0.654\end{array}$ & 0.684 & 0.752 & 0.864 \\
\hline
\end{tabular}

Note: Model measurement fits: $\chi^{2}=478,392, \mathrm{df}=156, p<0.001 ; \chi^{2} / \mathrm{df}=3.06$; CFI = 0.964; $\mathrm{TLI}=0.976 ; \mathrm{RMSEA}=0.041 ; \mathrm{SRMR}=0.058, \mathrm{AVE}=$ average variance extracted, $\mathrm{CR}=$ composite reliability.

Table 5. Correlation matrix Discriminant validity (square root of AVE in diagonal).

\begin{tabular}{cccccc}
\hline & PU & PUE & PR & PC & E-B \\
\hline PU & $\mathbf{0 . 7 7 4}$ & & & & \\
PUE & $0.365^{\star *}$ & $\mathbf{0 . 7 8 7}$ & & & \\
PR & $0.634^{\star *}$ & $0.221^{\star *}$ & $\mathbf{0 . 7 9 6}$ & & \\
PC & $0.498^{\star *}$ & $0.365^{\star *}$ & $0.651^{\star *}$ & $\mathbf{0 . 8 1 8}$ & \\
E-B & $0.176^{\star *}$ & $0.434^{\star}$ & $0.642^{\star *}$ & $0.547^{\star *}$ & $\mathbf{0 . 8 2 7}$ \\
\hline
\end{tabular}

Note: ${ }^{\star}$ Significant at the 0.05 level (two-tailed); ${ }^{\star}$ Significant at the 0.01 level (two-tailed).

\subsection{Goodness of Fit of Structural Model}

Table above showed the result of the path analyses with standardized coefficients the structural equation modeling results, like the measurement model, showed that the model fit for data $\left(\chi^{2}=478,392, \mathrm{df}=156, p<0.001 ; \chi^{2} / \mathrm{df}=3.06\right.$; CFI $=$ 0.964; TLI $=0.976 ;$ RMSEA $=0.041 ;$ SRMR $=0.058)$. 
Table 6. Structural equation modeling (SEM) results.

\begin{tabular}{cccccc}
\hline Hypotheses & Path & Coeff. & S.E. & $p$-value & Results \\
\hline H1 & PU $\rightarrow$ E-B & 0.148 & 0.002 & 0.006 & Supported \\
H2 & PUE $\rightarrow$ EB & 0.171 & 0.050 & 0.000 & Supported \\
H3 & PR $\rightarrow$ E-B & 0.151 & 0.040 & 0.000 & Supported \\
H4 & PC $\rightarrow$ E-B & 0.555 & 0.53 & 0.000 & Supported \\
\hline
\end{tabular}

Note: Model measurement fits: $\chi^{2}=478,392, \mathrm{df}=156, p<0.001 ; \chi^{2} / \mathrm{df}=3.06$; CFI = 0.964; $\mathrm{TLI}=0.976$; RMSEA $=0.041 ; \mathrm{SRMR}=0.058, \mathrm{AVE}=$ average variance extracted, $\mathrm{CR}=$ composite reliability.

H1. Perceived usefulness (PU) had a positive effect on adoption e-banking (E-B) $(\beta=0.148, p<0.05)$ indicating H2. The perceived ease of use (PEU) on E-B was also significantly positive $(\beta=0.171, p<0.05)$ and $\mathrm{H} 3$, perceived risk (PR) has positive effect to adoption of e-banking $(\beta=0.151, p<0.05)$, indicating that $\mathrm{H} 4$, Perceived credibility $(\mathrm{PC})$ has positive impact to adoption e-banking ( $\beta$ $=0.555, p<0.05$ (E-B), supporting. Overall, our research model clarified $60 \%$ of the variance in adoption of e-banking.

\section{Discussion}

This research has determined to clarify the adoption of e-banking services and clients in Mogadishu, Somalia, by extending the TAM. The finding of this paper is showing that four factors have a positive impact on e-banking adoption. This means that if clients have a favorable attitude toward e-banking and are more convinced in it and believe that adopting it will provide them with more significant benefit, their willingness to use it and recommend everyone to use it will rise. This outcome supports (Al-somali et al., 2008) assertion that there is a link between customer attitudes and internet banking adoption. In understanding the definition of Perceived ease of use, our findings reveal that it impacts together perceived usefulness and intention to adopt e-banking. This contradicts the findings from (Liu et al., 2003) who discovered that perceived ease of use influences perceived usefulness but had no effect on adoption attitudes. This investigation contributed to the existence of data showing perceived credibility, perceived ease of use, perceived risk, and perceived usefulness are helpful analysts of client perspectives of e-banking adoption. As a result of the current findings, if clients are aware of and perceive learning to use these services to be easy and to provide added value when it comes to keeping time and transaction security, they will create a positive perspective of the adoption of e-banking. People will be encouraged to adopt and usage these e-banking systems if they believe e-banking is trustworthy since online transactions hold sensitive information. They are sure the current bank will guarantee restricted access to their important data and documents. 
Additionally, the study highlighted that clients' perceptions of perceived credibility and perceived risk have a significant impact on e-banking adoption. Also, perceived usefulness and ease of use are the strong positive significant impact of adopting the e-banking service in Somalia.

Demographic characteristics are all of the respondents are between the ages of 20 and 59, and nearly seven-eighth (74.5\%) of them are completed high school and diploma college.

Consumers are more prefer to base their decision on perceived value or efficiency when determining whether or not to use e-banking. Furthermore, perceived credibility was revealed to be another important component that positively impact clients' intention to adopt e-banking. This is related to the results discovered by (Ochuko et al., 2009) and (Sohrabi, 2016). This showed that clients are becoming more aware of the risks associated with embracing new information technology and digital devices. Consumers will only want to utilize e-banking if it is seen to be "secure". Therefore, e-banking adoption will be unfeasible. Because all of the people who responded are adults aged between (21 to 60 ), they have a greater sense of self-preservation. However, most respondents are Internet users with more specific knowledge and more possibilities to use new technologies; they may indicate greater concerns about information privacy and technology security based on their personal experiences and comprehension of criminality. As a result, perceived credibility is a major factor to consider when selecting an online banking system. When it comes to the income level of all respondents on this study (58.1\%) respondents, earn 200 to $400 \$$ per monthly.

\section{Conclusion}

In Somalia, the banking system has seen impressive digital progress and provides e-banking system to customers as a whole. In developing and delivering banking-related processes and activities, recognizing clients' intention to assume e-banking becomes more popular. The research built a theoretical foundation to investigate the link between perceived ease of use, perceived usefulness, clients' intention, and perceived credibility, and perceived risk in the Somalia context of adopting e-banking services. With the statistical testing, the proposed research model and all the conclusions drawn in this research are applicable in the context of Somalia. The findings show that the significance of perceived ease of use and bank credibility, perceived risk; perceived usefulness is significant in improving clients' attitude towards the implementation and efficacy of e-banking systems. Then, has some potential to define and explain the main factors and variables-their contribution to impact the acceptance of e-banking. In specific, a weak point of adoption and information of e-banking in Mogadishu-Somalia was identified. However, the perceived usefulness and perceived credibility were described as the important variables that significantly affected the adoption of e-banking by users. Besides, three factors affecting clients' adoption of e-bank in Mogadishu were impossible to complete, needless to use, and safety concerns. 
TAM was extended, from a scientific viewpoint to consider how it could explain Somalia's adoption choices, specifically in Mogadishu, in describing the more basic features; the model was helpful and clear.

\section{Limitation and Further Research}

This paper has certain limitations to address, which must be remedied. The first constraint is the sample's geographical position as well as its scale. Future research should include a larger number of electronic banking users from a broader geographic region in Somalia Similarly, this research has the potential to increase the number of respondents aged 20 to 30 . Gender and age as socio-demographic variables that play a moderating impact were respected in this analysis. Previous scholars, for example (Natarajan et al., 2018), also underlined the significance of age in studies of mobile app acceptance. This variable's moderating function in the proposed model could be explored further. Finally, this model is solely founded on practical features of technology adoption, as either an instance, perceived ease of use and perceived usefulness, Authors of the field of e-banking (Natarajan et al., 2018) illustrated other forms of more emotional variables for the studies of e-banking service adoption, such as enjoyment or confidence. Similarly, (Srivastava, 2020) emphasizes perceived protection as a factor in e-banking adoption. As a consequence, a potential object could include an in e-banking environment, there is a blend of practical and emotional components. Lastly, further research may involve external variables relevant to e-banking service such us social influence, and System Infrastructure, further to investigate is to predict the theory planned behavior (TPB).

\section{Acknowledgements}

The authors wish to thank associate professor Lei Shanyu and Dalian university of technology professors also a school of economics and management.

\section{Conflicts of Interest}

The authors declare no conflicts of interest regarding the publication of this paper.

\section{References}

Alkailani, M. (2016). Factors Affecting the Adoption of Internet Banking in Jordan: An Extended TAM Model. Journal of Marketing Development \& Competitiveness, 10, 39-52.

Al-somali, S. A., Gholami, R., \& Clegg, B. (2008). Internet Banking Acceptance in the Context of Developing Countries: An Extension of the Technology Acceptance Model Internet Banking Acceptance in the Context of Developing Countries: An Extension of the Technology Acceptance Model. In European Conference on Management of Technology (pp. 1-16).

Arora, S., \& Kaur, S. (2018). Perceived Risk Dimensions \& Its Impact on Intention to USE E-Banking Services: A Conceptual Study. Journal of Commerce and Accounting Re- 
search, $7,19$.

Bagozzi, R., \& Yi, Y. (1988). On the Evaluation of Structure Equation Models. Journal of the Academy of Marketing Science, 16, 74-94. https://doi.org/10.1007/BF02723327

Bentler, P. M., \& Bonett, D. G. (1980). Significance Tests and Goodness of Fit in the Analysis of Covariance Structures. Psychological Bulletin, 8, 588-606. https://doi.org/10.1037/0033-2909.88.3.588

Bradley, L., \& Stewart, K. (2013). A Delphi study of the Drivers and Inhibitors of Internet Banking Delphi Questionnaire Distributed (Round). International Journal of Bank Marketing, 20, 250-260. https://doi.org/10.1108/02652320210446715

Case, T. H. E., \& Dashen, O. F. (2016). Opportunities and Challenges in the Adoption of E-Banking Services. Doctoral Dissertation, Addis Ababa University.

Cunningham, L. F., Gerlach, J., \& Harper, M. D. (2005). Perceived Risk and e-Banking Services: An Analysis from the Perspective of the Consumer. Global Journal of Business Research, 10, 165-178. https://doi.org/10.1057/palgrave.fsm.4770183

Davis (1989). Information Technology Introduction. Management Information Systems Research Center, University of Minnesota, 13, 319-340.

Davis, F. D. (2014). User Acceptance of Computer Technology: A Comparison of Two Theoretical Models. Management Science, 35, 982-1003.

Davis, F. D., \& Venkatesh, V. (1996). A Critical Assessment of Potential Measurement Biases in the Technology Acceptance Model: Three Experiments. International Journal of Human Computer Studies, 45, 19-45. https://doi.org/10.1006/ijhc.1996.0040

Fonchamnyo, D. C. (2013). Customers Perception of E-Banking Adoption in Cameroon: An Empirical Assessment of an Extended TAM. International Journal of Economics and Finance, 5, 166-176.

Fornell, C., \& Larcker, D. F. (1981). Evaluating Structural Equation Models with Unobservable Variables and Measurement Error. Journal of Marketing Research, 18, 39-50. https://doi.org/10.1177/002224378101800104

Geebren, A., Jabbar, A., \& Luo, M. (2021). Examining the Role of Consumer Satisfaction within Mobile Eco-Systems: Evidence from Mobile Banking Services. Computers in Human Behavior, 114, Article ID: 106584. https://doi.org/10.1016/j.chb.2020.106584

Hu, L., Bentler, P. M., \& Hu, L. (2009). Cutoff Criteria for Fit Indexes in Covariance Structure Analysis: Conventional Criteria versus New Alternatives Cutoff Criteria for Fit Indexes in Covariance Structure Analysis: Conventional Criteria versus New Alternatives. Structural Equation Modeling: A Multidisciplinary Journal, 6, 1-15. https://doi.org/10.1080/10705519909540118

Hu, Y., \& Liao, P. (2011). Finding Critical Criteria of Evaluating Electronic Service Quality of Internet Banking Using Fuzzy Multiple-Criteria Decision Making. Applied Soft Computing Journal, 11, 3764-3770. https://doi.org/10.1016/j.asoc.2011.02.008

Kabeer, A. (2013). Munich Personal RePEc Archive. An Empirical Study of Factors Influencing Adoption of Internet Banking among Students of Higher Education: Evidence from Pakistan. International Journal of Finance \& Banking Studies, 2, 48611. https://mpra.ub.uni-muenchen.de/48611

Kale, S. H., \& Mesiranta, N. (2008). Consumer Perceptions of Internet Banking in Finland: The Moderating Role of Familiarity. Bond University EPublications@bond.

Khurshid, A. (2014). Factors Contributing towards Adoption of E-Banking in Pakistan. International Journal of Accounting and Financial Reporting, 4, 437-455. https://doi.org/10.5296/ijafr.v4i2.6584

Kline, R. B. (2015). Principles and Practice of Structural Equation Modeling (4 ${ }^{\text {th }}$ ed.). 
Guilford Publications.

Liu, S., College, J. C., Company, Y. C., Koh, C. E., \& Kappelman, L. (2003). Standard User Interface in e-Commerce Sites. Industrial Management \& Data Systems, 103, 600-610. https://doi.org/10.1108/02635570310497648

Low, J., \& Abdul, M. (2013). Internet Banking-Benefits and Challenges in an Emerging Economy. International Journal of Research in Business Management, 1, 19-26.

Maduku, D. K. (2014). Customers Adoption and Use of e-Banking Services: The South African Perspective. Banks \& Bank Systems, 9, 67-77.

Markus, K. A. (2012). Structural Equation Modeling: A Principles and Practice of Structural Equation Modeling by Rex B. Kline. A Multidisciplinary Journal, 509-512, 37-41.

Masoud, E., Dhabi, A., Emirates, U. A., \& Abutaqa, H. (2017). Factors Affecting Customers Adoption of E-Banking Services in Jordan. Information Resources Management Journal, 30, 44-60. https://doi.org/10.4018/IRMJ.2017040103

Mohamed, M. I., Yakimin, Y., Talib, A., Utara, U., Abubakar, A. H., Ado, A. B., Sciences, M., Sultan, U., \& Abidin, Z. (2020). Factors Influencing the Adoption of E-Banking in Somalia. Iranian Journal of Accounting, Auditing \& Finance, 3, 23-36.

Mwiya, B. C. F., Shikaputo, C., Kabala, E. K., \& Siachinji, B. (2017). Examining Factors Influencing E-Banking Adoption: Evidence from Bank Customers in Zambia. American Journal of Industrial and Business Management, 7, 741-759.

https://doi.org/10.4236/ajibm.2017.76053

Natarajan, T., Balasubramanian, S. A., \& Kasilingam, D. L. (2018). Technology in Society The Moderating Role of Device Type and Age of Users on the Intention to Use Mobile Shopping Applications. Technology in Society Journal, 53, 79-90.

https://doi.org/10.1016/j.techsoc.2018.01.003

Ochuko, R. E., Cullen, A. J., \& Neagu, D. (2009). Overview of Factors for Internet Banking Adoption. In International Conference on CyberWorlds Overview (p. 9). https://doi.org/10.1109/CW.2009.51

Okari, O. D., \& Box, K. U. O. (2017). Consumer Perceived Risk of Internet Banking in Kenya: A Survey of Three Selected Banks in Nairobi County. International Journal of Science and Research, 6, 645-656.

Oni, A. A., \& Ayo, C. K. (2010). An Empirical Investigation of the Level of Users' Acceptance of e-Banking in Nigeria. Journal of Internet Banking and Commerce, 15, 1-13.

Poon, W. (2003). Case Study Users' Adoption of e-Banking Services: The Malaysian Perspective. Journal of Business \& Industrial Marketing, 23, 59-69. https://doi.org/10.1108/08858620810841498

PwC (2016). Online Shoppers around the World Are Fundamentally Disrupting Retail. PwC, Total Retail Survey, 22 (618).

Ramayah, T. (2015). Perceived Risk Factors Influence on Intention to Continue Using Internet Banking among Malaysians. Global Business Review, 15, 393-414. https://doi.org/10.1177/0972150915569928

Reynolds, B., Ortengren, A., Richards, J. B., \& de Wit, H. (2006). Dimensions of Impulsive Behavior: Personality and Behavioral Measures. Personality and Individual Differences, 40, 305-315. https://doi.org/10.1016/j.paid.2005.03.024

Riffai, M. M. M. A., Grant, K., \& Edgar, D. (2012). Big TAM in Oman: Exploring the Promise of On-Line Banking, Its Adoption by Customers and the Challenges of Banking in Oman. International Journal of Information Management, 32, 239-250. https://doi.org/10.1016/j.ijinfomgt.2011.11.007

Sabi, H. M. (2014). Research Trends in the Diffusion of Internet Banking in Developing 
Countries. Journal of Internet Banking and Commerce, 19, 1.

Sayid, O., Echchabi, A., \& Echchabi, H. A. A. A. (2012). Investigating Mobile Money Acceptance in Somalia: An Empirical Study. Pakistan Journal of Commerce and Social Sciences, 6, 269-281. https://www.econstor.eu

Siraye (2014). Customers' Adoption of Electronic Banking Service Channels in Ethiopia: An Integration of Technology Acceptance Model and Perceived Risk with Theory of Planned Behaviour Zeleke Siraye. International Journal of Electronic Finance, 8, 21-34. https://doi.org/10.1504/IJEF.2014.063993

Sohrabi, M. (2016). Critical Success Factor for the Adoption of e-Banking in Malaysia. International Arab Journal of Information Technology, 3, 2.

Srivastava, S. S. R. K. (2020). Understanding the Intention to Use Mobile Banking by Existing Online Banking Customers: An Empirical Study. Journal of Financial Services Marketing, 25, 86-96. https://doi.org/10.1057/s41264-020-00074-w

Surana, N., \& Sullivan, R. J. (2000). How Has the Adoption of Internet Banking Affected Performance and Risk in Banks? In the Tenth Federal Reserve District. 02.

Vyas, S. (2012). Impact of E-Banking on Traditional Banking Services.

Wheaton, B., Muthén, B., Alwin, D. F., \& Summers, G. F. (2014). Assessing Reliability and Stability. Sociological Methodology, 8, 84-136. https://doi.org/10.2307/270754

Wu, H., Lin, C., Li, C., \& Lin, H. (2010). A Study of Bank Customers' Perceived Usefulness of Adopting Online Banking. Global Journal of Business Research, 4, 101-108.

Xiao, Y., Sukumar, A., Tipi, L., \& Edgar, D. (2017). Factors Influencing People's Intention to Adopt E-Banking: An Empirical Study of Consumers in Shandong Province, China. Asian Journal of Computer and Information Systems, 5, 26-43.

Zhou, H., Romero, S. B., \& Qin, X. (2016). An Extension of the Theory of Planned Behavior to Predict Pedestrians' Violating Crossing Behavior Using Structural Equation Modeling. Accident Analysis \& Prevention, 95, 417-424.

https://doi.org/10.1016/j.aap.2015.09.009

Zhou, R., Wu, C., Rau, P.-L. P., \& Zhang, W. (2009). Young Driving Learners' Intention to Use a Handheld or Hands-Free Mobile Phone When Driving. Transportation Research Part F: Traffic Psychology and Behaviour, 12, 208-217.

https://doi.org/10.1016/j.trf.2008.11.003 